\title{
THE LOSS OF COLOUR IN RED WINES.
}

\section{By R. Greig Suith, D.Sc., Macleay Bacteriologist to the}

\section{Society.}

Two samples of red wine were obtained from a correspondent in South Australia, who gave me the following history of them:-

Sample A.-A dry red wine, 1900 vintage. It kept in good condition and order until April, 1903. In the cask it remained without much apparent change of condition. Upon removing a sample from the cask and exposing it to the air, it became perceptibly dull and threw down a copious black powdery deposit, which increased up to a certain limit. The wine then commenced to clear again. The wine contained short rod-like bacteria which, after exposure to the air, as detailed above, became fringed with débris.

Sample B.-A dry red wine, 1901 vintage. This wine appears to have been infected in bulk with the organisms of "vin tourné." It behaved like Sample A, but not to the same extent.

The bacteriological examinations of both samples showed that they contained a few moulds, Penicillium glaucum, and a great number of short rod-shaped bacteria, which grew very slowly upon nutrient glucose-gelatine, glucose-yeast-water-gelatine and alcohol (5\%)-yeast-water-gelatine. The colonies grew slowly and were always punctiform and microscopically circular and finely granular. In stroke culture upon the various gelatine media they grew slowly as a white narrow line, and did not liquefy the gelatine.

Small experimental flasks of an Australian claret were infected with the bacterium and placed in the incubator at $22^{\circ}$. In five days the wine had lost its brightness, while a slight film and sediment had formed. By the tenth day the wine had become decidedly lighter in colour; the film had become stronger and the 
deposit greater. Both film and deposit were coloured with the colouring matter of the wine.

A determination of the loss of colour was made by diluting 5 c.c. of the wine with 45 c.c. of water and comparing the depth of colour of this with similarly diluted wine from a control flask. The colour of the diluted 5 c.c. of infected wine was matched by 50 c.c. of diluted wine, containing $4 \cdot 2$ c.c. of the control wine. The infected wine had, therefore, suffered a loss of $16 \%$ of its original colour.

The infected wine had also become more acid. Normally the wine contained 7 milligrams of volatile acid in 10 c.c., while the infected wine at the end of ten days contained 298 milligrams of volatile acid in the same quantity. The acid is expressed as acetic, for it was shown to be such by the appearance and analysis of the silver salt.

The experimentally infected wine had, while losing its colour, deposited a coloured sediment, which consisted of dark-coloured zooglœa masses of bacteria. The phenomenon differed materially from what had been observed in the case of the wine from which the sample had been taken. Upon removal from the cask and exposure to the air, it had become dull and had thrown down a powdery deposit. The two phenomena are, therefore, quite different, but it must be remembered that the wines were under widely different conditions. The experimental wines were small in quantity (20 c.c.) and had been under aërobic conditions for a short time. The natural wine had been contained in casks, where the bulk had been for a long time under practically anaërobic conditions. Probably under the adverse conditions the aërobic bacteria had practically ceased to multiply, but had continued to secrete their oxidases, giving them off to the wine, so that upon exposure to the air the colouring matter was quickly oxidised to an insoluble darker-coloured product which slowly settled as a deposit.

What is generally known as the loss of colour of red wine is recognised as a complex process, ${ }^{*}$ inasmuch as there are certain

* Lafar, Technical Mycology, London (1898), i., 311. 
subordinate phenomena associated with the disease while the wine is in the cask. The malady shows itself first by an evolution of gaseous carbon dioxide; then the alcohol is converted to acetic acid, and finally a putrefactive fermentation ensues. Many bacteria have been isolated from such wines by various investigators from Pasteur in 1865 to Galeazzi in 1894; but in all cases the bacteria either had not been purified or experimental evidence as to their infectious nature had not been adduced. In order to produce the various stages, Lafar concludes that a number of organisms are probably necessary. He writes :- "A single bacterial species is insufficient to occasion the complaint, the successive action of a number of species is essential."

If we consider the chief phases of the disease, viz., the loss of colour, we find that there appears to be no reason why it might not be caused by the action of an acetic organism. In an allied disease, the browning of white wine, "la casse," the wine when poured from the cask into a glass vessel becomes darker in colour, especially in the upper layers. The colour spreads downwards, the wine becomes turbid, and finally a fine dark powder is deposited. The formation of a deposit is similar to what occurs in "vin tourné," and doubtless it was this that caused the loss of colour of red wine to be for a long time classed with the browning of white wine. In the latter disease it is at present accepted that the phenomenon is caused by an enzyme, which plays the part of a carrier of oxygen, that is, an oxidase. The oxygen of the air is absorbed by it and given up to the colouring matter and tannins of the wine, which are converted into insoluble and darkcoloured compounds.

Since it is admitted* that an oxidase causes the formation of a dark powdery deposit in the case of "vin cassé," there appears to be no reason why an oxidase should not also be responsible for the similar formation of a dark powdery deposit in the loss-ofcolour stage of "vin tourné." It is true that in the one case an oxidase has been isolated and not in the other, but that may 
simply be a matter of technique. The acetic bacteria are the oxidising bacteria par excellence, and they must do their work by means of oxidases which they produce and possibly excrete. Since acetic bacteria were the only bacteria detected in the wines under investigation, there is every reason to believe that they were responsible for the loss of colour.

The only objection to this claim is that experimentally the sudden formation of a powdery deposit was not obtained. In place of it a slow precipitation occurred concomitantly with the sedimentation of the bacteria. The difference is probably merely one in the time through which the phenomenon extended, and might be explained by the difference between the natural and the experimental conditions.

Attempts were made to produce the sudden precipitation of the colouring matter of the wine by subjecting infected samples of wine to various anaërobic and partly anaërobic conditions during times varying from a week to a month, but without success. When the cultures were again exposed to the air no change occurred. This does not necessarily mean that the bacteria cannot produce the phenomenon, but it means that they cannot do so under laboratory conditions. Under natural conditions, such as the infection of the wine in bulk and storage for a year or more, another result might have been obtained.

The bacterium appears to be a race of Bact. ascendens, Henneberg. It forms a delicate film which creeps high up the sides of the culture flasks; it is easily broken and falls to the bottom of the wine as a flocculent precipitate. The cells are not stained by iodine, they are non-motile and are not arranged in threads, but occur singly, in pairs and in masses. The white opalescence upon the medium around the colonies on nutrient glucose gelatine was not observed, but this is not enough to constitute it as a new species. When contained in wine it is killed by an exposure to $43^{\circ} \mathrm{C}$. for ten minutes.

[Printed off August 2nd, 1904.] 


\section{$2 \mathrm{BHL}$ Biodiversity Heritage Library}

Greig-Smith, Robert. 1904. "The loss of colour in red wines." Proceedings of the Linnean Society of New South Wales 29, 213-216.

https://doi.org/10.5962/bhl.part.20161.

View This Item Online: https://www.biodiversitylibrary.org/item/30005

DOI: https://doi.org/10.5962/bhl.part.20161

Permalink: https://www.biodiversitylibrary.org/partpdf/20161

\section{Holding Institution}

MBLWHOI Library

Sponsored by

MBLWHOI Library

\section{Copyright \& Reuse}

Copyright Status: NOT_IN_COPYRIGHT

This document was created from content at the Biodiversity Heritage Library, the world's largest open access digital library for biodiversity literature and archives. Visit BHL at https://www.biodiversitylibrary.org. 